\title{
Thermally activated persulfate treatment and mineralization of a recalci- trant high TDS petrochemical wastewater
}

\author{
Sahand Jorfi ${ }^{1,2 *}$, Sudabeh Pourfadakari ${ }^{3}$, Mehdi Ahmadi ${ }^{1,2}$, Hamideh Akbari ${ }^{4}$ \\ ${ }^{1}$ Ahvaz Jundishapur University of Medical Sciences, Environmental Technologies Research Center, Ahvaz, Iran \\ ${ }^{2}$ Ahvaz Jundishapur University of Medical Sciences,Department of Environmental Health Engineering, School of Health, \\ Ahvaz, Iran \\ ${ }^{3}$ Ahvaz Jundishapur University of Medical Sciences, Department of Environmental Health Engineering, School of Health, \\ Ahvaz, Iran \\ ${ }^{4}$ Zahedan University of Medical Sciences, Department of Environmental Health Engineering, School of Health, Zahedan, Iran \\ *corresponding author: sahand369@yahoo.com
}

\begin{abstract}
Thermally activated persulfate efficiency for the treatment of a recalcitrant high TDS wastewater was investigated. The specific character of studied wastewater was high TDS content of around $23820 \mathrm{mg} / \mathrm{L}$ and BOD5/COD ratio of 0.07. Effective operational parameters including initial $\mathrm{pH}$ values of 3-9, reaction temperature of $40-80^{\circ} \mathrm{C}$ and persulfate concentrations of $0.5-5 \mathrm{~g} / \mathrm{L}$ for COD removal were investigated in batch mode experiments. Removal efficiency was $\mathrm{pH}$ and temperature dependent. The COD and TOC removal of $94.3 \%$ and $82.8 \%$ were obtained at persulfate concentration of $4 \mathrm{~g} / \mathrm{L}$, initial $\mathrm{pH}$ value of 5 and temperature of $70^{\circ} \mathrm{C}$ after $180 \mathrm{~min}$ for initial COD concentration of $1410 \mathrm{mg} / \mathrm{L}$. The pseudo first-order kinetic model was best fitted with COD removal $(\mathrm{R} 2=0.94)$.
\end{abstract}

Keywords: Industrial wastewater treatment, Thermally activation, persulfate Petrochemical industry, High TDS wastewater.

\section{INTRODUCTION}

The rapid growth of petrochemical industries in last two decades and widespread use of petrochemical products has led to serious environmental contamination, especially water bodies receiving considerable amounts of wastewaters originated from these industries ${ }^{1}$. Petrochemical effluents contain significant amounts of hazardous organic and inorganic chemical compounds such as halogenated hydrocarbons, aromatic compounds, phenolic substances, oil and grease, aliphatic, polycyclic aromatic hydrocarbons (PAHs) and heavy metals which all possess high toxicity to plants, animals and also human beings ${ }^{2-4}$. In addition, a major portion of petrochemical wastewaters are characterized as high TDS that along with containing aromatic constituents make them resistant to biodegradation ${ }^{5}$. Many of halogenated hydrocarbons, aromatics and phenolic substances are categorized as priority pollutants causing carcinogenic and mutagenic effects which necessitate application of efficient treatment methods before being discharged to water bodies ${ }^{6}$. A range of physical, chemical and biological processes and their integration such as integration of advanced oxidation with coagulation , biodegradation using special microorganisms ${ }^{7,8}$ membrane filtration, chemical precipitation, photocatalytic degradation using nanoparticles ${ }^{9}$ advanced oxidation processes (AOPs) are investigated for treatment of petrochemical industries ${ }^{10-13}$ Low $\mathrm{BOD}_{5} / \mathrm{COD}$ ratio of less than 0.1 and high TDS content of produced wastewater limits direct application of biological processes .Additionally, conventional chemical oxidations and precipitations are not efficient enough especially in term of soluble organic matter and xenobiotics. $\mathrm{AOP}_{\mathrm{s}}$ are based on the generation of nonselective and strong oxidative radicals like hydroxyl and sulfate and recently are successfully employed for treatment of such recalcitrant wastewaters ${ }^{14-16}$. Oxidation through activated persulfate is an attractive option due to its high stability, reactivity, solubility, oxidizing properties and rapid rate of organic matter destruction ${ }^{17}$. Persulfate
$\left(\mathrm{S}_{2} \mathrm{O}_{8}{ }^{2-}\right)$ with the standard oxidation potential of $\mathrm{E}^{0}=2.01$ $\mathrm{V}$ is a quite new alternative used in chemical oxidation and recently received much attention in the treatment of biological resistant wastewaters. In addition, activation of $\mathrm{S}_{2} \mathrm{O}_{8}{ }^{2-}$ leads to initiate sulfate radical based-AOPs that are powerful oxidants ${ }^{18}$. Sulfate radical $\left(\mathrm{SO}_{4}^{-{ }^{-}}, \mathrm{E}^{0}=2.7\right.$ $\mathrm{V}$ ), is a strong oxidant for the degradation of organic matter even at neutral $\mathrm{pH}$ and acts more selective for the treatment of wastewaters containing compounds with carbon-carbon double bonds and benzene rings ${ }^{19}$. Activation of persulfate can be accomplished by various methods including heat, transit metal, base (elevated $\mathrm{pH}>11$ ), UV-radiations, electron-beam and ultrasonication $^{20}$. For practical issues in term industrial wastewater treatment, UV irradiation cannot penetrate in wastewater efficiently and alkaline activation needs large amounts of alkaline chemical that produces considerable excess sludge. Furthermore, transit metal-catalyzed activation (for example $\mathrm{Fe}^{2+}$ ) exhibits best results in strict $\mathrm{pH}$ value range of 2-4 and may metal may act as a sulfate radical scavenger ${ }^{21}$. Compared to other activation technologies, thermally activated persulfate is considered as a green source of sulfate radicals and has already been studied for removal of organic contaminants ${ }^{22,23}$. Thermally activation of persulfate has also advantages such as increasing the solubility of slightly soluble organic pollutants, enhancing the reaction rates and mineralization efficiency and least consumption of chemicals ${ }^{24}$, ease of operation and simple simplicity ${ }^{25}$, minimization of persulfate consumption caused by pre-mixture of the persulfate and the activator before injection $^{26}$. In the current study, thermally activated persulfate was investigated for the treatment of a high TDS petrochemical wastewater characterized by $\mathrm{BOD}_{5} / \mathrm{COD}$ ratio of less than 0.1 which according to literature review has not been studied before. The influences of effective operational parameters as well as kinetics were investigated for treatment of a real petrochemical wastewater. 


\section{EXPERIMENTAL}

\section{Material}

Sodium persulfate $\left(\mathrm{Na}_{2} \mathrm{~S}_{2} \mathrm{O}_{8}, 98 \%\right)$, Sodium hydroxide $(\mathrm{NaOH}, 96 \%)$ and hydrochloric acid $(\mathrm{HCl}, 99 \%)$ were all analytical grade and obtained from Merck, Germany. Real high TDS wastewater sample was taken from a petrochemical industry located in the south of Iran. The samples collected from the outlet line of raw effluent according to standard methods for the examination of water and wastewater ${ }^{27}$. It was transported to the lab in cold box at $4^{\circ} \mathrm{C}$ daily and wastewater characteristics including $\mathrm{COD}, \mathrm{BOD}_{5}$, TSS, TDS and $\mathrm{pH}$ were analy$\mathrm{zed}^{27}$. The sampling was carried out during six months with weekly time intervals. Also the sampling was done in morning shift as the peak of the industrial manufacturing process and therefore wastewater production. For each sampling, $5 \mathrm{~L}$ of wastewater sample was prepared by mixing the separate samples originated from $1 \mathrm{~h}$ sampling intervals to prepare a composite sample in each day. The results of raw wastewater are the avarice of six months continues monitoring.

\section{Batch experimental procedure}

Determination of optimum conditions of the operational parameters including initial $\mathrm{pH}$ (3-9), temperature $\left(40-80^{\circ} \mathrm{C}\right)$ and persulfate concentration $(0.5-5 \mathrm{~g} / \mathrm{L})$ according to one factor at the time experimental design were carried out in a $500 \mathrm{~mL}$ Erlenmeyer flask as completely mixed batch reactor using a magnetic stirrer equipped with an electronic contact thermometer (IKA, Model: C-MAG HS 7, Germany). In order to set the reactor temperature, rather than heater stirrer a water jacket was provided with adjustable temperature surrounding the reactor. The desired initial $\mathrm{pH}$ value was adjusted with $\mathrm{NaOH}(1 \mathrm{M})$ or $\mathrm{HCl}(1 \mathrm{M})$ solutions before starting the experiment. Sampling was implemented in 20 min time intervals during a contact time range of $0-120 \mathrm{~min}$. Also, zero-order, pseudo-first-order and pseudo-second-order kinetic models were evaluated for experimental data.

\section{Analytical methods}

Characterization of raw wastewater in term of chemical oxygen demand (COD), biochemical oxygen demand $\left(\mathrm{BOD}_{5}\right)$, Total dissolved solids (TDS), total suspended solids (TSS), electrical conductivity (EC) and $\mathrm{pH}$ were carried out according to standard methods for the examination of water and wastewater ${ }^{27}$. Qualitative analysis of wastewater constituents were determined by gas chromatography-mass spectrometry (GC-MS) analysis (Model: Agilent 7890, USA) with HP-5MS capillary column $(30 \mathrm{~m} \times 0.25 \mathrm{~mm} \times 0.25 \mu \mathrm{m}$ film thickness, $5 \%$ Phenyl - 95\% Methyl Siloxane phase). A constant flow rate of $1 \mathrm{~mL} / \mathrm{min}$ was employed to feed the carrier gas (Helium). The temperature rate of oven was firstly set to $40^{\circ} \mathrm{C}$ for $1 \mathrm{~min}$ then increased to $300^{\circ} \mathrm{C}$ at $5^{\circ} \mathrm{C} / \mathrm{min}$. This temperature was maintained for 3 min. Finally, the sample was injected into the instrument at a splitting ratio of 10:1. The removal efficiency (\%) was calculated based on COD concentration via $\mathrm{Eq}(1)$ :

Removal $(\%)=\left(\mathrm{C}_{0}-\mathrm{C}_{\mathrm{t}}\right) / \mathrm{C}_{0} \times 100$
Where $\mathrm{C}_{0}$ is the initial COD concentration $(\mathrm{mg} / \mathrm{L})$ and $\mathrm{C}_{\mathrm{t}}$ is the COD concentration $(\mathrm{mg} / \mathrm{L})$ at specified reaction time $\mathrm{t}(\mathrm{min})$. Total organic carbon (TOC) was measured using a TOC analyzer (Shimadzu, TOC-VCSH, Japan) to determine the mineralization. All the experimental data are expressed in terms of arithmetic averages obtained from at least three replicates.

\section{RESULTS AND DISCUSSION}

\section{Petrochemical wastewater characterization}

The average concentrations of total COD, $\mathrm{BOD}_{5}$, TDS and TSS of raw wastewater according to two week sampling with daily interval were $1320 \mathrm{mg} / \mathrm{L}, 95,23820$ $\mathrm{mg} / \mathrm{L}$ and $63 \mathrm{mg} / \mathrm{L}$, respectively (Table 1 ). The low $\mathrm{BOD}_{5} /$ COD ratio of 0.07 indicates the non-biodegradable nature of studied petrochemical wastewater and the necessity for investigation chemical transformation processes. According to a GC-MS analysis (Table 2), the principle identified organic compounds of raw wastewater included: benzene and benzene derivates, naphthalene, o-terphenyl, p-Dicyclohexylbenzene, 1-phenyl-3-phenylthio-butane, n-benzhydrylimidazole and heptane.

Table 1. Characteristics of a real petrochemical wastewater sample

\begin{tabular}{|l|c|c|}
\hline \multirow{2}{*}{ Parameter } & \multicolumn{2}{|c|}{ Value } \\
\cline { 2 - 3 } & range & average \\
\hline Total COD [mg/L] & $1080-1430$ & 1320 \\
\hline $\mathrm{BOD}_{5}[\mathrm{mg} / \mathrm{L}]$ & $86-100$ & 95 \\
\hline $\mathrm{BOD}_{5} / \mathrm{COD}$ & $0.05-0.09$ & 0.07 \\
\hline TOC & $780-925$ & 842 \\
\hline TSS & $56-70$ & 63 \\
\hline TDS & $19650-42780$ & 23820 \\
\hline pH & $7.8-9.4$ & 8.7 \\
\hline Turbidity & $18-30$ & 20 \\
\hline
\end{tabular}

Table 2. GC-MS chromatogram of raw petrochemical wastewater

\begin{tabular}{|l|c|c|}
\hline Run time [min] & Substance & Structural formula \\
\hline 14.485 & Benzene & $\mathrm{C}_{6} \mathrm{H}_{6}$ \\
\hline 15.984 & 1-methyl-2-nitro-Benzene & $\mathrm{C}_{7} \mathrm{H}_{7} \mathrm{NO}_{2}$ \\
\hline 15.984 & 4-Nitrotoluene & $\mathrm{C}_{7} \mathrm{H}_{7} \mathrm{NO}_{2}$ \\
\hline 32.210 & Naphthalene & $\mathrm{C}_{10} \mathrm{H}_{8}$ \\
\hline 31.450 & 2(5H)-Furanone & $\underline{\mathrm{C}}_{4} \underline{\mathrm{H}}_{4} \underline{\mathrm{O}}_{2}$ \\
\hline 32.091 & o-Terphenyl & $\mathrm{C}_{18} \underline{\mathrm{H}}_{14}$ \\
\hline 34.002 & Hexane & $\mathrm{C}_{6} \mathrm{H}_{14}$ \\
\hline 34.254 & 3-phenyl thio-ethane & $\mathrm{C}_{8} \mathrm{H}_{10} \mathrm{~S}$ \\
\hline 34.861 & 1,4-dicyclohexyl & $\underline{\mathrm{C}}_{18} \underline{\mathrm{H}}_{26}$ \\
\hline 35.610 & 2-methyl benzaldehyde & $\mathrm{C}_{8} \mathrm{H}_{8} \mathrm{O}$ \\
\hline 36.354 & 9,10-Anthracenedione & $\underline{\mathrm{C}}_{14} \underline{\mathrm{H}}_{8} \underline{\mathrm{O}_{2}}$ \\
\hline
\end{tabular}

\section{Effect of temperature}

To determine the effect of temperature on COD removal at different activation temperatures $\left(40-80^{\circ} \mathrm{C}\right)$, a constant persulfate concentration of $1 \mathrm{~g} / \mathrm{L}$ was added at initial $\mathrm{pH}$ value of 7 . Increasing the activation temperature from 40 to $80^{\circ} \mathrm{C}$ enhanced the COD removal from $21.6 \%$ to $44.01 \%$ respectively (Fig. 1). However, the temperature of $70^{\circ} \mathrm{C}$ with removal efficiency of $42.3 \%$ was selected for investigation the effect of $\mathrm{pH}$ and persulphate dosage due to no significant deference between removal at $70^{\circ} \mathrm{C}$ and $80^{\circ} \mathrm{C}$ ( $\mathrm{p}$-value of $\left.0.0146<0.05\right)$ according to non-parametric Kruskal Wallis statistical analysis. COD removal using $\mathrm{SO}_{4}{ }^{\cdot}$ radicals is a temperature dependent process and removal could be enhanced through increase 
in temperature. It could be attributed to the enhanced generation of sulfate based radicals at elevated ${ }^{28}$. Results of current study in term of temperature effect are in accordance with literature ${ }^{29,30}$. Mechanism of persulfate oxidation through heat catalysts which leads production of sulfate radicals for degradation of organic matter can be explained through Eqs. (2-6) as bellow ${ }^{31}$ :

$$
\begin{aligned}
& \mathrm{S}_{2} \mathrm{O}_{8}^{2-}+\text { Heat } \rightarrow 2 \mathrm{SO}_{4}^{--} \\
& \mathrm{SO}_{4}^{--}+\mathrm{H}_{2} \mathrm{O} \rightarrow \mathrm{SO}_{4}^{2-}+\mathrm{HO}^{\bullet}+\mathrm{H}^{+} \\
& \mathrm{SO}_{4}^{--}+\mathrm{R} \rightarrow \mathrm{SO}_{4}^{--}-\mathrm{R} \\
& \mathrm{SO}_{4}^{--}-\mathrm{R} \rightarrow \mathrm{SO}_{4}^{2-}+\mathrm{R}^{\cdot} \\
& \mathrm{HO}^{-}+\mathrm{R} \rightarrow \mathrm{OH}^{-}+\mathrm{R}^{\cdot}
\end{aligned}
$$

As indicated above (Eq. 2), persulfate can be catalyzed by heat which leads to formation of free radicals of $\mathrm{SO}_{4}{ }^{-\cdot}$. Formation of sulfate radicals in aqueous phase would result in production of the hydroxyl radical $\left(\mathrm{HO}^{\circ}\right.$, $\left.\mathrm{E}^{\mathrm{o}}=+2.7 \mathrm{~V}\right)$ through radical inter-conversion reactions ${ }^{33}$. In accordance with Eqs. 5 and 6, both $\mathrm{SO}_{4}{ }^{-}$and $\mathrm{HO}^{\circ}$

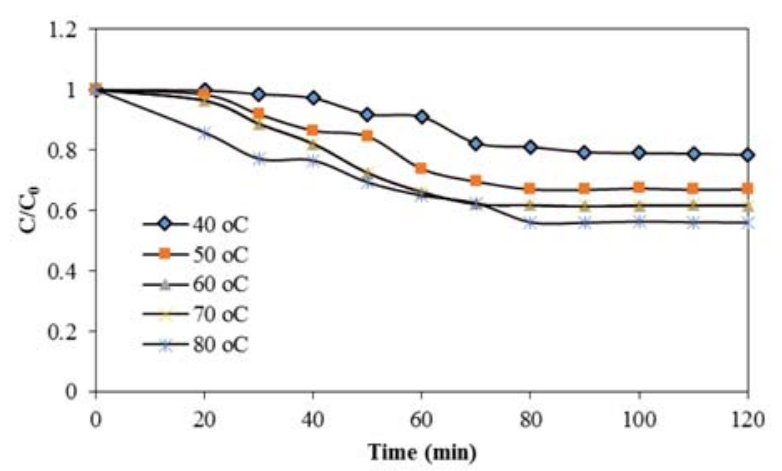

Figure 1. Effect of temperature on COD removal of petrochemical wastewater using thermally activated persulfate, $\mathrm{pH}$ : 7, reaction time: $0-120 \mathrm{~min}$, persulfate concentration: $1 \mathrm{~g} / \mathrm{L}$

radicals are responsible for oxidation of recalcitrant organic matter in heat activated persulfate oxidation process.

\section{Effect of the persulfate concentration}

In order to determine the effect of persulfate concentration on COD removal, different persulfate concentrations $(0.5-5 \mathrm{~g} / \mathrm{L})$ were added to solution at initial $\mathrm{pH}$ value of 7 and temperature of $70^{\circ} \mathrm{C} \mathrm{(Fig.2).} \mathrm{Increasing} \mathrm{persulfate}$ concentration from 0.5 to $5 \mathrm{~g} / \mathrm{L}$, enhanced the COD removal from $17.76 \%$ to $72.96 \%$. Near COD removal of about $87 \%$ for initial persulfate dosage of 4 and $5 \mathrm{~g} / \mathrm{L}$ can be explained by this effect Persulfate concentration $4 \mathrm{~g} / \mathrm{L}$ was considered as the selected level for remaining experiments because of acceptable removal efficiency, beside less chemical usage and non-significant difference of removal efficiency ( $\mathrm{p}$-value $<0.0065$ ) according to non-parametric Kruskal Wallis statistical analysis. This is due to the fact that higher persulfate concentration will produce higher $\mathrm{SO}_{4}{ }^{\circ}$ radical in solution during heat activation $^{34}$. According to literature an increase in the initial persulfate dosage in acidic $\mathrm{pH}$ above a critical concentration would not continuously increase the removal efficiency, because persulfate acts as a scavenger of sulfate radicals as shown in Eq. (7) ${ }^{35}$ :

$$
\begin{aligned}
& \mathrm{SO}_{4}{ }^{-\bullet}+\mathrm{S}_{2} \mathrm{O}_{8}^{2-} \rightarrow \mathrm{SO}_{4}^{2-}+\mathrm{S}_{2} \mathrm{O}_{8}^{-\bullet} \\
& \mathrm{k}=5.5 \times 10^{5} \mathrm{M}^{-1} \mathrm{~S}^{-1}
\end{aligned}
$$

Ji et al. (2015) observed that increasing the persulfate concentration from $0.1 \mathrm{mM}$ to $2 \mathrm{mM}$ enhanced the COD removal from $10 \%$ to $98 \%$ for groundwater remediation ${ }^{36}$.

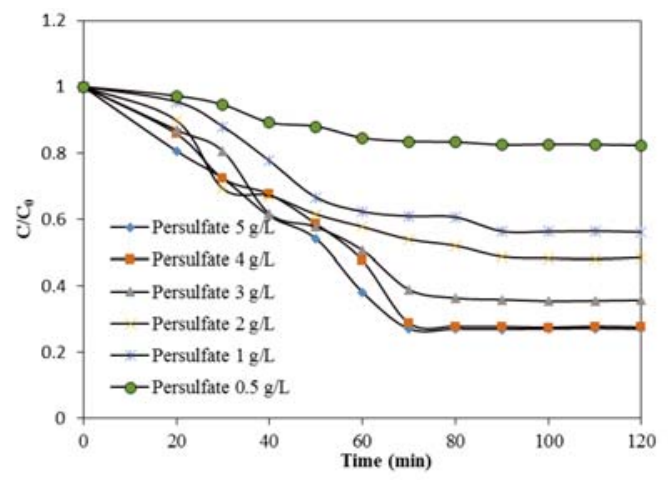

Figure 2. Effect of persulfate concentration on COD removal for petrochemical wastewater using thermally activated persulfate, $\mathrm{pH}: 7$, temperature: $70^{\circ} \mathrm{C}$, reaction time: $0-120 \mathrm{~min}$

\section{Effect of initial pH}

Effect of $\mathrm{pH}$ on COD removal was evaluated at persulfate concentration of $4 \mathrm{~g} / \mathrm{L}$, temperature of $70^{\circ} \mathrm{C}$ and varying $\mathrm{pH}$ range of 3-9 (Fig. 3). Results indicated that acidic $\mathrm{pH}$ values favored COD removal and the most removal efficiencies of $87 \%, 86.67 \%$ and $86.02 \%$ were observed for initial $\mathrm{pH}$ values of 3,4 and 5 respectively. This can be attributed to rapid conversion of $\mathrm{SO}_{4}{ }^{\circ}$ radicals to $\mathrm{OH}^{*}$ radicals at basic conditions. In addition, more sulfate radicals could be generated through acid catalyzation in acidic condition, which might accelerate the COD removal2 ${ }^{22,37,38}$. In accordance with current study finding, Kordkandi et $\mathrm{al}^{39}$ (2014).reported that decreasing initial $\mathrm{pH}$ from 9.3 to 2.3 led to increase in dye removal from $65 \%$ to $96 \%$. In another recent study by Zou (2014) on decolourization of methyl orange using persulfate, $\mathrm{pH} 5$ was reported as optimized leve ${ }^{40}$. Also, Deng and Ezyske ${ }^{41}$ reported low $\mathrm{pH}$ value of 4 for as the optimum level. It should be noted that COD removal at initial $\mathrm{pH}$ value of 9 was still considerable (about $62 \%$ ) which can be attributed to persulfate activation via alkaline condition. The effect of basic $\mathrm{pH}$ on persulfate activation has been discussed by Abu Amr (2013) ${ }^{18}$, as bellow (Eq. (8) $)^{42}$ :

$$
\mathrm{S}_{2} \mathrm{O}_{8}^{2-}+\mathrm{OH} \rightarrow \mathrm{HSO}_{4}^{--}+\mathrm{SO}_{4}^{-\bullet}+1 / 2 \mathrm{O}_{2}
$$

\section{Kinetic study}

The kinetic parameters of zero, pseudo first and second-order kinetic models including rate of the persulfate oxidation reaction for petrochemical wastewater were determined by plotting $\mathrm{C}_{\mathrm{t}}$ against time, $-\ln \left(\mathrm{C}_{0} /\right.$ $C_{t}$ ) against time and $1 / C_{t}$ against time respectively (Fig. 4) in selected conditions including $\mathrm{pH}$ value of 5 , persulfate concentration of $4 \mathrm{~g} / \mathrm{L}$ and temperature of $70^{\circ} \mathrm{C}$. The individual kinetic equations are as bellow (Eq. (9) zero order, Eq. (10) first - order and Eq. (11) second-order ${ }^{43,44}$ : 


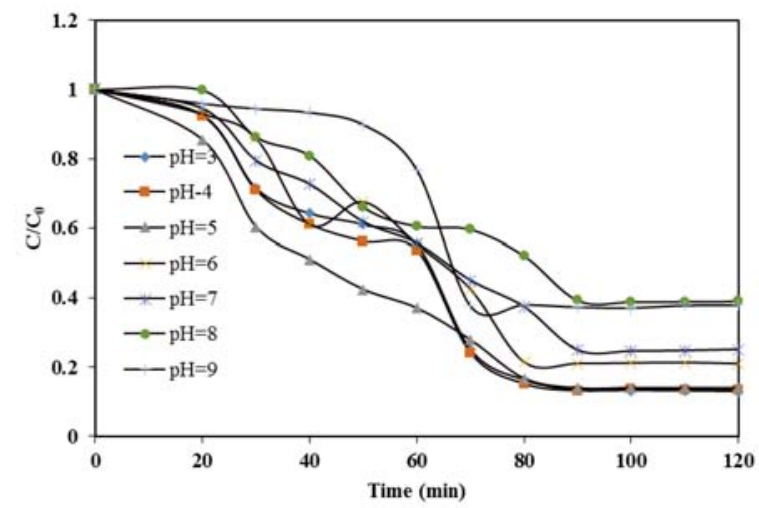

Figure 3. Effect of initial $\mathrm{pH}$ on COD removal of petrochemical wastewater using thermally activated persulfate, persulfate concentration: $4 \mathrm{~g} / \mathrm{L}$, temperature: $70^{\circ} \mathrm{C}$, reaction time: $0-120 \mathrm{~min}$

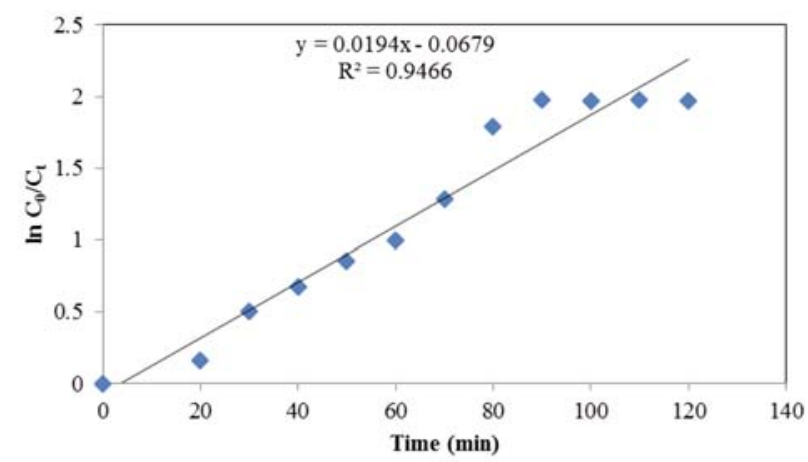

Figure 4. Pseudo first-order kinetic analysis of persulfate oxidation petrochemical wastewater, $\mathrm{pH}$ : 5 , persulfate concentration: $4 \mathrm{~g} / \mathrm{L}$, temperature: $70^{\circ} \mathrm{C}$

$\mathrm{C}_{\mathrm{t}}=\mathrm{C}_{0}-\mathrm{k}_{0} \mathrm{t}$

$\ln \mathrm{C}_{0} / \mathrm{C}_{\mathrm{t}}=\mathrm{k}_{1} \mathrm{t}$

$1 / \mathrm{C}_{\mathrm{t}}-1 / \mathrm{C}_{0}=\mathrm{k}_{2} \mathrm{t}$

where $\mathrm{C}_{0}$ is the initial COD concentration in the solution $(\mathrm{mg} / \mathrm{L}), \mathrm{C}_{\mathrm{t}}$ is the residual COD concentration in the solution $(\mathrm{mg} / \mathrm{L}), \mathrm{t}$ is the reaction time $(\mathrm{min})$, and $\mathrm{k}_{\mathrm{n}}$ is the corresponding rate constants $(\mathrm{n}=0,1$ and 2$)$. The reaction kinetics of COD removal through persulfate oxidation of petrochemical wastewater fitted well for pseudo first-order reaction with regression coefficient of 0.94 and rate constant of $0.019 \mathrm{~min}^{-1}$. The details of the kinetic parameters are presented in Table 3.

Table 3. The kinetic parameters for zero order, pseudo first and pseudo second order models in thermally activated persulafte treatment of petrochemical saline wastewater

\begin{tabular}{|l|c|c|}
\hline Kinetic Model & Parameter & Amount \\
\hline \multirow{2}{*}{ Zero Order } & $\mathrm{K}_{0}$ & - \\
\cline { 2 - 3 } & $\mathrm{R}^{2}$ & 0.892 \\
\hline \multirow{2}{*}{ First Order } & $\mathrm{K}_{1}$ & 0.019 \\
\cline { 2 - 3 } Second Order & $\mathrm{R}^{2}$ & 0.946 \\
\cline { 2 - 3 } & $\mathrm{K}_{2}$ & 0.00005 \\
\hline
\end{tabular}

\section{Mineralization and intermediate metabolites}

To determine the potential of thermally activated persulfate for mineralization of petrochemical wastewater, TOC removal compared to COD was evaluated at the reaction time of $180 \mathrm{~min}$. Mineralization study was conducted at the initial COD concentration of $1410 \mathrm{mg} / \mathrm{L}$, persulfate concentration of $4 \mathrm{~g} / \mathrm{L}$, the initial $\mathrm{pH}$ of 5 and temperature of $70^{\circ} \mathrm{C}$. Although a COD removal of $94.3 \%$ was observed within a reaction time of $180 \mathrm{~min}$, the TOC removal reached $82.8 \%$ at the same operational conditions (Fig. 5). Production of intermediate byproducts such as Hexanoic acid, Cyclotrisiloxane, 5-Methyl1-nitropyrazole,1,1,1-trichloro-N-Acetylpyrrolidone, Benzaldehyde, Benzeneacetonitrile, Cyclotetrasiloxane, Benzene, O-Dichlorobenzene, Nitro-Benzene, Ethylbenzaldehyde, 1-ethenyl-4-methoxy, 2,5-Dihydroxyacetophenone, Bis(trimethylsilyl) ether, 2-Chloro-6-nitrotoluene, 6-Chitrotoluene, 1-Chloro-2-methyl-3-nitrobenzene, 4-Chloro-2-nitrotoluene, 2,5-Dichlornitrobenzen, 1-Nitro-3,4-dichlorobenzene, 2-methyl-1,3-dinitro-Benzene, Cyclohexyldimethylsilyloxyoctadecane, Pentachloro-Benzene, Thiocyanic acid carbazol-3,6-diylester, Octadecane, Sulfurous acid, Phthalic acid, 1,2-Benzenedicarboxylic acid, Isobutyl nonyl ester, Benzoic acid, 3,6-tricarbonitrile, Bis(2-ethylhexyl) phthalate, 1,2-Benzenedicarboxylic acid, Bis(2-ethylhexyl) phthalate is the main reason for lower TOC removal (Table 4). These organic byproducts are resistant to further degradation within studied time interval and proceeding the reaction or increasing persulfate concentration maybe effective for fully mineralization ${ }^{45}$. In accordance with current study results Cai et al (2014), in their study on chemically activation of peroxydisulfate for degradation of Orange II dye reported that TOC removal was less than that of COD removal efficiency ${ }^{46}$.

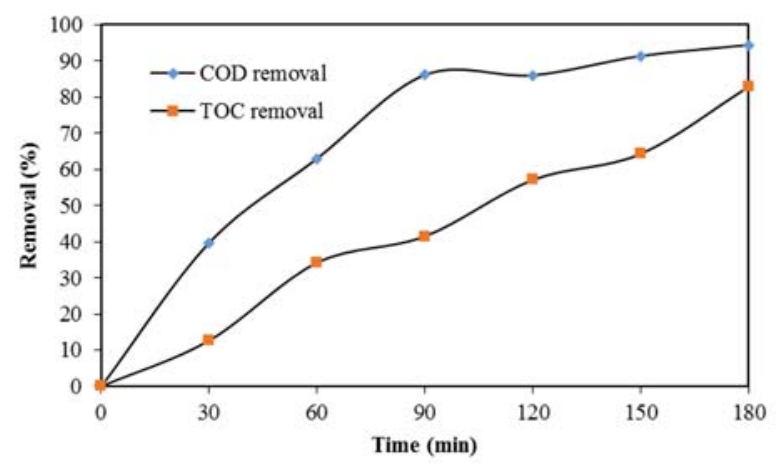

Figure 5. Mineralization of petrochemical wastewater by thermally activated persulfate within $180 \mathrm{~min}$ of reaction in comparison with COD removal efficiency [\%]

Table 4. GC-MS chromatogram of treated petrochemical wastewater by thermally activated persulfate on produced intermediates, initial COD: $1410 \mathrm{mg} / \mathrm{L}$, persulfate concentration: $4 \mathrm{~g} / \mathrm{L}, \mathrm{pH}$ : 5 , temperature: $70^{\circ} \mathrm{C}$, reaction time: $180 \mathrm{~min}$

\begin{tabular}{|l|c|c|}
\hline $\begin{array}{l}\text { Run time } \\
\text { [min] }\end{array}$ & Constituent & $\begin{array}{c}\text { Structural } \\
\text { formula }\end{array}$ \\
\hline 14.714 & Benzaldehyde & $\mathrm{C}_{7} \mathrm{H}_{6} \mathrm{O}$ \\
\hline 16.711 & Cyclotetrasiloxane & $\mathrm{C}_{48} \mathrm{H}_{40} \mathrm{O}_{4} \mathrm{Si}_{4}$ \\
\hline 17.289 & Acetic acid & $\mathrm{CH}_{3} \mathrm{COOH} \mathrm{H}$ \\
\hline 18.599 & Benzene & $\mathrm{C}_{6} \mathrm{H}_{6}$ \\
\hline 18.777 & 1-chloro-2-methyl-3-nitro & $\mathrm{C}_{7} \mathrm{H}_{6} \mathrm{CINO}_{2}$ \\
\hline 22.771 & toluene & $\mathrm{C}_{7} \mathrm{H}_{6} \mathrm{~N}_{2} \mathrm{O}_{4}$ \\
\hline 28.819 & Thiocyanic acid carbazol & $\underline{\mathrm{C}}_{14} \underline{\mathrm{H}}_{7} \underline{\mathrm{N}}_{3} \underline{\mathrm{S}_{2}}$ \\
\hline 30.341 & Octadecane & $\mathrm{C}_{18} \mathrm{H}_{38}$ \\
\hline 31.778 & Phthalic acid & $\mathrm{C}_{6} \mathrm{H}_{4}\left(\mathrm{COOH}_{2}\right.$ \\
\hline 32.233 & Benzoic acid & $\mathrm{C}_{7} \mathrm{H}_{6} \mathrm{O}_{2}$ \\
\hline 32.361 & Nonadecane & $\mathrm{C}_{19} \mathrm{H}_{40}$ \\
\hline 36.143 & Heneicosane & $\mathrm{C}_{21} \mathrm{H}_{44}$ \\
\hline 37.550 & Phenol & $\mathrm{C}_{6} \mathrm{H}_{6} \mathrm{O}$ \\
\hline 43.593 & Bis(2-ethylhexyl) phthalate & $\mathrm{C}_{24} \mathrm{H}_{38} \mathrm{O}_{4}$ \\
\hline
\end{tabular}


Their results indicated that after $60 \mathrm{~min}$, the removal efficiencies of (COD) and (TOC) were $52.1 \%$ and $31.9 \%$, respectively and in contact time $24 \mathrm{~h}$ reached to $82.9 \%$ and $51.5 \%$, respectively.

\section{CONCLUSIONS}

In the current study, COD removal from high TDS recalcitrant wastewater originated from petrochemical industry was subjected to thermally activated persulfate was investigated Operational parameters including temperature, persulfate concentration and initial $\mathrm{pH}$ were as evaluated. Increasing the persulfate concentration and the wastewater temperature up to a specified value, along with decreasing the initial $\mathrm{pH}$ to acidic range favored the COD removal. Organic matter removal of wastewater followed pseudo-first-order kinetic model. The experimental results showed that the degradation of COD was progressively influenced by reaction temperature and concentration of persulfate. In selected conditions, considerable mineralization of up to $82.8 \%$ was observed based on TOC removal after $180 \mathrm{~min}$. remaining organic matter was comprised of intermediate metabolites such as Hexanoic acid, Benzaldehyde, 2, 5-Dichlornitrobenzen based on GC-MS analysis of final effluent. According to the findings of the current study, it can be concluded that thermally activated persulfate can be considered as an efficient and reliable alternative for treatment of high TDS wastewaters containing recalcitrant organic matter. Finally, more research for modification of obtained results is proposed specially in term of minimizing persulfate dosage. For high flow rates, a persulfate dosage of 5 $\mathrm{mg} / \mathrm{L}$ is high and would be expensive.

\section{ACKNOWLEDGEMENT}

This research Project has been financially supported by Ahvaz Jundishapur University of Medical Sciences (Grant no ETRC 9504).

\section{LITERATURE CITED}

1. Botalova, O.S., Frauenrath, J. \& Dsikowitzky, T.L. (2009). Identification and chemical characterization of specific organic constituents of petrochemical effluents. Water Res. 43(15), 3797-3812. DOI: org/10.1016/j.watres.2009.06.006.

2. Cechinel, M.A.P.M., Pozdniakova, D.A., Mazur, T.A., Boaventura, L.P. \& Rui, A.R. (2016). Removal of metal ions from a petrochemical wastewater using brown macro-algae as natural cation-exchangers. J. Chem. Eng. 286, 1-15. DOI: org/10.1016/j.cej.2015.10.042.

3. Kalantary, R.R., Mohseni-Bandpi, A., Esrafili, A., Nasseri, S., Ashmagh, F.R., Jorfi, S. \& Ja'fari, M. (2014). Effectiveness of biostimulation through nutrient content on the bioremediation of phenanthrene contaminated soil. J. Environ. Health Sci. Eng. 24,12(1),143. DOI: 10.1186/s40201-014-0143-1.

4. Rezaei Kalantary, R.B.A., Mohseni Bandpi, A., Esrafili, A. \& Jorfi, S. (2013). Modification of PAHs Biodegradation with Humic Compounds. J. Soil \& Sedim. Contamin. 22, 185-198. DOI: org/10.1080/15320383.2013.722139.

5. Lefebvre, O. \& Moletta, R. (2006). Treatment of organic pollution in industrial saline wastewater: a literature review. Water Res. 40(20), 3671-3682. DOI: org/10.1016/j. watres.2006.08.027.

6. Yeo, I.A., Yoon, S.H. \& Yee, J.J. (2013). Development of an urban energy demand forecasting system to support environmentally friendly urban planning. Appl. Energy 110, 304-317. DOI: org/10.1016/j.apenergy.2013.04.065.

7. Jorfi, S., Rezaee, A., Mobeh-Ali, G.A. \& Jaafarzadeh, N.A. (2013) Application of Biosurfactants Produced by Pseudomonas aeruginosa SP4 for Bioremediation of Soils Contaminated by Pyrene. J. Soil \& Sedim. Contamin. 22, 890-911. DOI: org/1 0.1080/15320383.2013.770439.

8. Tayybi, T., Jorfi, S., Ghaffari, S. \& Kujlu, R. 2016. Bioremediation of n-hexadecane contaminated soils using pseudomonas aeruginosa bacteria isolated from coastal areas. J. Mazan.Uni. Med. Sci. 26(140), 127-136.

9. Ahmadi, M.R.M.H.R., Jaafarzadeh, N., Mostoufid, A., Saeedie, R., Barzegarc, G. \& Jorfia, S. (2017). Enhanced photocatalytic degradation of tetracycline and real pharmaceutical wastewater using MWCNT/TiO 2 nano-composite. J. Environ. Manage 186, 55-63. DOI: org/10.1016/j.jenvman.2016.09.088

10. Namata, N. \& Patil, S.R.S. (2015). Degradation of Reactive Yellow 145 dye by persulfate using microwave and conventional heating. J. Water Process. Eng. 7, 314-327. DOI: org/10.1016/j.jwpe.2015.08.003.

11. Soltani, R.D.J.S., Ramezani, H. \& Purfadakari, S. (2016). Ultrasonically induced $\mathrm{ZnO}$-biosilica nanocomposite for degradation of a textile dye in aqueous phase. Ultra. Sonochem 28, 69-78. DOI: 10.1016/j.ultsonch.2015.07.002.

12. Sundarapandiyan, S.C.R., Ramanaiah, B., Krishnan, S. \& Saravanan, P. (2010). Electrochemical oxidation and reuse of tannery saline wastewater. J. Hazard Mater. 180(1-3), 197-203. DOI: org/10.1016/j.jhazmat.2010.04.013.

13. Jorfi, S.D.C.S.R., Ahmadi, M., Khataeed, A. \& Safarie, M. (2017). Sono-assisted adsorption of a textile dye on milk vetch-derived charcoal supported by silica nanopowder. J Environ Manage. 187, 111-121. DOI: org/10.1016/j.jenvman.2016.11.042

14. Darvishi Cheshmeh Soltani, R.J., Safari, S. \& Rajaei, M.M.S. (2016). Enhanced sonocatalysis of textile wastewater using bentonite-supported $\mathrm{ZnO}$ nanoparticles: Response surface methodological approach. J. Environ. Manage. 179, 47-57. DOI: org/10.1016/j.jenvman.2016.05.001.

15. Naddeo, V.C.A. (2013). Wastewater Treatment by Combination of Advanced Oxidation Processes and Conventional Biological Systems. J. Bioremed. Biodeg. 4, 208. DOI: 10.4172/2155-6199.1000208.

16. Yang, Q.X.P., Ding, P., Chu, L. \& Wang, J. (2015). Treatment of petrochemical wastewater by microaerobic hydrolysis and anoxic/oxic processes and analysis of bacterial diversity. Biores. Technol. 196, 169-175. DOI: org/10.1016/j. biortech.2015.07.087.

17. Xiong, X.S.B., Zhang, J., Gao, N., Shen, J., Li, J. \& Guan, X. (2014). Activating persulfate by $\mathrm{Fe}(0)$ coupling with weak magnetic field: performance and mechanism. Water Res.62, 53-62. DOI: org/10.1016/j.watres.2014.05.042.

18. Abu Amr, S.S.A. \& Adlan, M.N. (2013). Optimization of stabilized leachate treatment using ozone/persulfate in the advanced oxidation process. Waste Manag. 33(6), 1434-1441. DOI: org/10.1016/j.wasman.2013.01.039.

19. Qi, C.L., Xitao L., Chunye Z., Xiaohui M., Jun, T.H. \& Ye, W. (2014). Degradation of sulfamethoxazole by microwave-activated persulfate: Kinetics, mechanism and acute toxicity. J. Chem. Eng. 249, 6-14. DOI: org/10.1016/j.cej.2014.03.086.

20. Furman, O.S., Teel, A.L. \& Watts, R.J. ( 2010). Mechanism of base activation of persulfate. Environ. Sci. Technol. 44, 6423-6428. DOI: 10.1021/es1013714.

21. Liang, C.J. (2010). Mass transfer and chemical oxidation of naphthalene particles with zerovalent iron activated persulfate. Environ. Sci. Technol. 44, 8203-8208. DOI: 10.1021/es903411a.

22. Tan, C.G., Deng, N., Yang, A., \& Deng, N. (2012). Heat-activated persulfate oxidation of diuron in water. J. Chem. Eng. 203, 294-300. DOI: org/10.1016/j.seppur.2013.03.003.

23. Weng, C.H. \& Tsai, K.L. (2016). Ultrasound and heat enhanced persulfate oxidation activated with $\mathrm{Fe}(0)$ aggregate 
for the decolorization of C.I. Direct Red 23. Ultr. Sonochem. 29, 11-18. DOI: org/10.1016/j.ultsonch.2015.08.012.

24. Ji, Y., Shi, Y., Dong, W., Wen, X., Jiang, M. \& Lu, J. (2016). Thermo-activated persulfate oxidation system for tetracycline antibiotics degradation in aqueous solution. J. Chem. Eng. 298, 225-233. DOI: org/10.1016/j.cej.2016.04.028.

25. Fan, Y.J.Y., Kong, D., Lu, J. \& Zhou, Q. (2015). Kinetic and mechanistic investigations of the degradation of sulfamethazine in heat-activated persulfate oxidation process. $J$ Hazard Mater. 300, 39-47. DOI: org/10.1016/j.jhazmat.2015.06.058.

26. Tan, C., Gao, N., Deng, Y., Rong, W., Zhou, S. \& Lu, N. (2013). Degradation of antipyrine by heat activated persulfate. Separat. Purif. Technol. 109, 122-128. DOI: 10.1016/j. seppur.2013.03.003.

27. APHA: Standard Methods for the Examination of Water \& Wastewater. twenty first ed. American Public Health Assoiation, Washington, DC 2005.

28. Chen, X.M.M. \& Zhang, Y. (2016). Degradation of p-Nitrophenol by thermally activated persulfate in soil system. J. Chem. Eng. 283, 1357-1365. DOI: org/10.1016/j.cej.2015.08.107.

29. Vicente, F., Santos, A., Romero, A. \& Rodriguez, S. (2011). Kinetic study of diuron oxidation and mineralization by persulphate: Effects of temperature, oxidant concentration and iron dosage method. J. Chem. Eng. 170(1), 127-135. DOI: org/10.1016/j.cej.2011.03.042.

30. Zhang, M., Chen, X., Zhou, H., Murugananthan, M. \& Zhang, Y. (2015). Degradation of p-nitrophenol by heat and metal ions co-activated persulfate. J. Chem. Eng. 264, 39-47. DOI: org/10.1016/j.cej.2014.11.060.

31. Gao, Y.Q., Gao, N.Y., Deng, Y., Yang, Y.Q. \& Ma, Y. (2012). Ultraviolet (UV) light-activated persulfate oxidation of sulfamethazine in water. J. Chem. Eng. 195-196, 248-253. DOI: org/10.1016/j.cej.2012.04.084.

32. Yang, S., Yang, X., Shao, X., Niu, R. \& Wang, L. (2011). Activated carbon catalyzed persulfate oxidation of Azo dye acid orange 7 at ambient temperature. J. Hazard. Mater. 186(1), 659-666. DOI: org/10.1016/j.jhazmat.2010.11.057.

33. Yang, S., Wang, P., Yang, X., Wei, G., Zhang, W. \& Shan, L. (2009). A novel advanced oxidation process to degrade organic pollutants in wastewater: Microwave-activated persulfate oxidation. J. Environ. Sciences. 21(9), 1175-1180. DOI: 10.1016/ S1001-0742(08)62399-2.

34. Vicente, F.S.A., Sagüillo, E.G. \& Villacorta, A.M. (2012). Diuron abatement in contaminated soil using Fenton-like process. J. Chem. Eng. 183, 357-364. DOI: org/10.1016/j. cej.2012.01.010

35. Hori, H.Y.A., Hayakawa, E., Taniyasu, S., Yamashita, N., Kutsuna, S. \& Kiatagawa, H. (2005). Efficient Decomposition of Environmentally Persistent Perfluorocarboxylic Acids by Use of Persulfate as a Photochemical Oxidant. J. Environ. Sci. Technol. 39, 2383-2388. DOI: 10.1021/es0484754.

36. Ji, Y., Dong, C., Kong, D., Lu, J. \& Zhou, Q. (2015). Heat-activated persulfate oxidation of atrazine: Implications for remediation of groundwater contaminated by herbicides. J. Chem. Eng. 263, 45-54. DOI: org/10.1016/j.cej.2014.10.097.

37. Deng, J., Shao, Y., Gao, N., Deng, Y., Zhou, S. \& Hu, X. (2013). Thermally activated persulfate (TAP) oxidation of antiepileptic drug carbamazepine in water. J. Chem. Eng. 228, 765-771. DOI: org/10.1016/j.cej.2013.05.044.

38. Park, S., Lee, L.S., Medina, V.F., Zull, A. \& Waisner, S. (2016). Heat-activated persulfate oxidation of PFOA, 6:2 fluorotelomer sulfonate, and PFOS under conditions suitable for in-situ groundwater remediation. Chemosphere 145, 376-383. DOI: 10.1016/j.chemosphere.2015.11.097.

39. Kordkandi, S.A. \& Forouzesh, M. (2014). Application of full factorial design for methylene blue dye removal using heat-activated persulfate oxidation. J. Taiwan Ins. Chem. Eng. 45(5), 2597-2604. DOI: org/10.1016/j.jtice.2014.06.015.

40. Zou, J., Ma, J., Zhang, X. \& Xie, P. (2014). Rapid spectrophotometric determination of peroxymonosulfate in water with cobalt-mediated oxidation decolorization of methyl orange. J. Chem. Eng. 253, 34-39. DOI: org/10.1016/j.cej.2014.05.042.

41. Deng, Y. \& Ezyske, C.M. (2011). Sulfate radical-advanced oxidation process (SR-AOP) for simultaneous removal of refractory organic contaminants and ammonia in landfill leachate. Water Res. 45(18), 6189-6194. DOI: org/10.1016/j. watres.2011.09.015.

42. Furman, O.S., Teel, A, Ahmad, M. \& Watts, R.J. (2011). Effect of Basicity on Persulfate Reactivity. J. Environ. Eng. 137(4), 241-247. DOI: 10.1061/ (ASCE) EE.1943-7870.0000323.

43. Ahmadian, M.Y., Van Ginkel, N., Zare, S.W., Rahimi, M.R. \& Fatehizadeh, S.A. (2012). Kinetic study of slaughterhouse wastewater treatment by electrocoagulation using $\mathrm{Fe}$ electrodes. Water Sci. Technol. 66(4), 754-760. DOI: 10.2166/ wst.2012.232.

44. Huang, R., Fang, Z., Fang, X. \& Tsang, E.P. (2014). Ultrasonic fenton-like catalytic degradation of bisphenol a by ferroferric oxide(fe3o4) nanoparticles prepared from steel pickling waste liquor. J. Coll. \& Inter Sci. 436, 258-266. DOI: org/10.1016/j.jcis.2014.08.035.

45. Jorfi, S., Barzegar, G., Ahmadi, M., Darvishi Cheshmeh Soltani, R., Alah Jafarzadeh Haghighifard, N., Takdastan, A., Saeedi, R. \& Abtahi, M. (2016). Enhanced coagulation-photocatalytic treatment of Acid red 73 dye and real textile wastewater using UVA/synthesized $\mathrm{MgO}$ nanoparticles. $J$. Environ. Manage 177, 111-118. DOI: 10.1016/j. jenvman. DOI: org/10.1016/j.jcis.2014.08.035.

46. Cai, C.Z., Zhong, H. \& Hou, X.L. (2014). Electrochemical enhanced heterogeneous activation of peroxydisulfate by $\mathrm{Fe}$ -Co/SBA-15 catalyst for the degradation of Orange II in water. Water Res. 66, 473-485. DOI: org/10.1016/j.watres.2014.08.039. 